\title{
Never Social and Entrepreneurial Enough? Exploring the Identity Work of Social Entrepreneurs from a Psychoanalytic Perspective
}

Michaela Driver, Ph.D.

School of Business

Western State Colorado University

221 Borick Business Building

Gunnison, Colorado 81231

USA

Tel: $970-943-2673$

Fax: 970-943-7042

E-mail: mdriver@western.edu

\section{Biographical Note:}

Michaela researches alternative and psychoanalytic approaches to a wide range of organizational topics such as organizational identity and learning, trust, emotions, spirituality, corporate social responsibility, identity work, creativity, embodied subjectivity and leadership. Journals in which Michaela's work has been published include Organization Studies, Human Relations, Organization, Management Learning, Journal of Organizational Change Management, Academy of Management Learning \& Education, Journal of Business Ethics, and Journal of Management Inquiry. She serves on several editorial boards including Organization, Management Learning, Organization Studies and the Journal of Management Inquiry. 


\title{
Never Social and Entrepreneurial Enough? Exploring the Identity Work of Social Entrepreneurs from a Psychoanalytic Perspective
}

\begin{abstract}
Building on an analysis of interviews with 61 social entrepreneurs, the study offers a more finegrained exploration of the identity work of social entrepreneurs from a psychoanalytic, particularly Lacanian, perspective. Specifically, it suggests that what defines social entrepreneurial identity work is the blurring of beatific and horrific aspects of fantasies and a desire for struggle and lack. This in turn creates an emancipatory space in which discursive movement enables alternative forms of market enjoyment and ethical agency. The latter unsettles macro discourses of capitalism by demanding and amplifying their lack. The study contributes new avenues for exploring Lacanian concepts such as the traversal of fantasy as a product of discursive movement particularly relevant for transformative readings of identity narratives.
\end{abstract} Key Words: Identity, Social Entrepreneurship, Lacan, Psychoanalysis, Discourse

\section{Introduction}

While there is no universally accepted definition of social entrepreneurship (Peredo and McLean, 2006; Teasdale, 2011; Zahra, 2009), researchers generally agree that social entrepreneurship is a specific kind of entrepreneurship (Smith, Besharov, Wessels and Chertok, 2012) consisting of the "creative use of resources to generate both social and economic value" (Miller, Wesley and Williams, 2012: 351) with social value referring to activities that address social problems (Dacin, Dacin and Tracey, 2010). Social entrepreneurship generally serves as an umbrella term that includes non-profit organizations as well as for-profit businesses with some philanthropic or socially responsible activities (Alter, 2004; Peredo and McLean, 2006; Tan, William and Tan, 2005). While social entrepreneurship is often praised as a powerful solution to 
social ills and a more humane capitalism (Zografos, 2006), others are concerned that problems produced by the market should not be addressed through market-based endeavors (GibsonGraham, 2006) and that social entrepreneurship discourse represents a thinly veiled attempt at expanding capitalist logics to pressure and undermine public service organizations (Dey, 2006; Dey and Steyart, 2010).

Amidst all the praise and controversy, social entrepreneurs struggle to manage what researchers refer to as a dual identity seeking to integrate "business principles with social objectives" (Paulsen and McDonald, 2010: 109) and manage the often "complex demands of this double bottom line" (Miller et al., 2012: 351). As a result, recent research has focused on the identity work of social entrepreneurs (Jones, Latham and Betta, 2008) and highlighted the need to better understand it (Miller, Grimes, McMullen and Vogus: 2012: 630). In particular, there have been calls for more research on the struggles often faced by social entrepreneurs (Miller et al., 2012; Pache and Chowhury, 2012; Smith and Woodworth, 2012) as they construct what some have labelled as their "contested identities" (Howorth, Smith and Parkinson, 2012: 386).

This study follows such calls and explores the experiences and struggles of social entrepreneurs examining, among other things, whether identity work leads social entrepreneurs to subjugate themselves to an expanding entrepreneurial ideology or whether there is room for resistance and emancipation. Identity work is defined here as "the ongoing mental activity that an individual undertakes in constructing and understanding of self" (Alvesson, Ashcraft and Thomas, 2008: 15) usually articulated as a narrative drawn from a variety of discourses (Brown and Lewis, 2011) with the aim of coherence or stability but usually "under construction" (Ybema, Keenoy, Beverungen, Ellis and Sabelis, 2009) and in process rather than stasis (Alvesson et al., 2008). 
Building on prior research in which social entrepreneurship was examined using a psychoanalytic perspective (Froggett and Chamberlayne, 2004) and entrepreneurship more generally from a Lacanian perspective as the pursuit of an impossible object of desire (Jones and Spicer, 2005; 2009), my goal is to explore how social entrepreneurial struggles can be understood in the context of unconscious desire and fantasies. I analyze specifically how social entrepreneurs build identities around horrific and beatific fantasies, which both center on struggle as a defining characteristic. On the one hand, social entrepreneurs come to their occupation by experiencing struggles, such as losing a parent, or suffering from ill health. On the other hand, they seek to work through such experiences by struggling to help others in need, being attuned to their hardships and working in a system they criticize for being uncaring and exploitative. I examine how all of this informs an understanding of social entrepreneurial identity work as an emancipatory space in which fantasmatic attachments can be unsettled and ethical agency is enhanced by keeping identity in movement.

There are several contributions I hope to make with this research. One is to offer an empirical application of this framework and to focus more, as some have called for, on the micro narratives of social entrepreneurship (Hervieux, Gedajlovic and Turcotte, 2010; Vasi, 2009) providing a more nuanced analysis of social entrepreneurial identity work as a crucial dimension of social entrepreneurship as a contested identity (Howorth et al., 2012; Miller et al., 2012; Pache and Chowhury, 2012; Smith and Woodworth, 2012) and how this is experienced by social entrepreneurs. Further, my aim is to add to current debates in the field about whether social entrepreneurship discourse is a site of ideological domination of an expanding entrepreneurial logic (Dey and Steyaert, 2010; Jones and Murtola, 2012) or a site of resistance and emancipation (Howorth et al., 2012). It seems that narrative self-constructions amplify both while serving an 
empowering discursive movement in which social entrepreneurs can play with different subject positions and traverse the fantasy of finding fulfillment through market enjoyment (Byrne and Healy, 2006: 243). The study contributes directions for future research on alternative forms of enjoyment, an economy of desire and the temporary traversal of fantasies as well as transformational approaches to post-fantasmatic research (Byrne and Healy, 2006).

The paper proceeds by providing an overview of relevant debates in social entrepreneurship research followed by an outline of key Lacanian concepts. This is followed by a description of research methods and a detailed analysis of the data. The paper concludes by discussing the complexities of social entrepreneurial identity work in light of a psychoanalytic reading and the implications of this for social entrepreneurship as an emancipatory project.

\section{Social Entrepreneurship}

The term social entrepreneurship originated in the idea that non-profits needed to engage in entrepreneurial or market-driven activities to become less dependent on public moneys and fundraising (Zietlow, 2001). It was popularized by policy-makers to further privatize public services and to support ideologies of marketization by suggesting that social entrepreneurship is morally more desirable than traditional models of public service institutions (Dey and Steyaert, 2010; Seanor and Meaton, 2008). As a result, social entrepreneurs became celebrated through successful case studies of "true social entrepreneurship" (Thompson, Alvy and Lees, 2000: 333) as heroic visionaries (Vasi, 2009) and morally superior individuals (Bornstein, 1998) who work for a higher purpose (Dempsey and Sanders, 2010). Social entrepreneurs are depicted as innovative and smart and even more driven to succeed than some for-profit entrepreneurs as they face potentially difficult and risky circumstances creating not only market opportunities but social value (Boschee and McClurg, 2003; Dees and Economy, 2001; Martin, 2004). 
Social entrepreneurs are often considered heroes because of their own difficult or even tragic circumstances. This is well illustrated by the case of George Willdridge who set up a center for problem gamblers after overcoming his own gambling addiction (Roberts and Woods, 2005: 50). The authors describe why he did not use his considerable talents to return to his former life as a successful business executive, because "his life has a different purpose now" (Roberts and Woods, 2005: 50). He is "a different person" who understands that "quality of life does not stem from wealth" (Roberts and Woods, 2005: 50). He appears to be "genuine" and "sincere" and has a "mission to save good people from a bad path" (Roberts and Woods, 2005: 50). The authors conclude that not only is he a man who is using "his talents for a social cause" (Roberts and Woods, 2005: 50), "George Willdridge is a practicing social entrepreneur who has pursued an opportunity for transformative social change" (Roberts and Woods, 2005: 50).

However, research has also shown that social entrepreneurs themselves may not necessarily agree with the glowing reviews they have been given. George Willdridge, for example, is actually irritated by the label social entrepreneur as it does not reflect how he sees himself (Roberts and Woods, 2005: 50). Other social entrepreneurs are conflicted about the label social entrepreneur because it either does not capture accurately what they are doing or because it actually has misleading associations in their minds, such as being too lofty or linked to being in a higher demographic strata. For example, one study of social entrepreneurs found that the label was resented by many of the interviewees as either irrelevant or denigrating, as entrepreneurship was often associated with not being concerned with social and political struggles, holding lower moral standards or as pretentious (Parkinson and Howorth, 2008).

Some have argued that the whole concept of social entrepreneurship should be rejected because it promotes a seductive and powerful ideology that we should take care not to buy into 
(Dempsey and Sanders, 2010) offering only decaf resistance (Contu, 2008) at the level of the symptom while leaving underlying capitalist ideologies unquestioned (Cremin, 2012: 46). Others argue that social entrepreneurship discourse will either have negative consequences, such as corrupting and undermining not-for-profits (Eikenberry, 2009), or should simply be dismissed as a grandiose discourse (O'Connor, 2006). Such tensions, as I will illustrate below, may be better understood from a psychosocial perspective (Fotaki, Long and Schwartz, 2012: 1113) and the struggle with who social entrepreneurs think they are and how they signify what they desire.

\section{The Social Entrepreneurial Self}

To explore this further, I now turn to psychoanalysis, specifically Lacanian psychoanalysis, as one theoretical framework that might give us more purchase on understanding social entrepreneurial identity work especially in view of its unconscious dynamics. I should note here that a Lacanian perspective, while praised as providing relevant and important insights into a number of management and organization issues (Contu, Driver and Jones, 2010), is only one of many I could have used here. That is, my interpretation is designed to illustrate social entrepreneurial identity work from a Lacanian perspective "to illustrate a mode of experience" (Costas and Fleming, 2009: 364) and I am mindful that the data "could very well be interpreted differently if studied from another theoretical perspective" (Costas and Fleming, 2009: 364).

Having said that, it is important to keep in mind that a Lacanian perspective has been found significant especially in view of the study of identity in organizations (Driver, 2009a;b) and has been used to illuminate a number of important organizational issues from subjectivity to power (Arnaud, 2002; Arnaud and Vanheule, 2007; Cremin, 2009; Roberts, 2005; Stavrakakis, 2008). I will try to build on this work as well as Lacan's own writings (1977a;b; 1988a;b) to 
explicate ideas relevant to the analysis below noting that this can be challenging as Lacan's writing is intentionally open-ended (Fink, 2004: 65).

As noted by Jones and Spicer (2005; 2009), key to understanding entrepreneurial selfconstructions from a Lacanian perspective is that the subject is "structured around an unsignifiable lack" (ibid: 233) and that "it is this inability to close the gap within ourselves, to 'truly become ourselves', that keeps us becoming, identifying and speaking” (ibid: 233). While individual efforts may be designed to cover up this lack, all one can ever manage are narratives of becomingness (Harding, 2007) that strengthen illusions of stability (Roberts, 2005) rather than fulfill real desires. Particularly, individuals construct fantasies by which they cover over and protect themselves from the anxiety of lack (Byrne and Healy, 2006: 243). These fantasies have a beatific and horrific side (Glynos, 2008), with beatific referring to how lack can be overcome and desire fulfilled, and horrific referring to various obstacles along the way. This further subjugates individuals to imaginary dependencies including ideologies and institutional logics (Glynos, 2008) because things that might get in the way of attaining objects of desire can be seen as mere temporary obstacles maintaining the fantasy that wish-fulfillment is possible in the first place (Byrne and Healy, 2006: 243). This then explains why individuals may cling to certain ideologies, such as marketization or entrepreneurship, despite evidence that they do not offer what was promised, which is blamed on some temporary loss of enjoyment rather than a permanent structural lack (Glynos; 2008).

Therefore, key to understanding the entrepreneurial self from a Lacanian perspective are the fantasies and inevitably flawed illusions that Lacan called the order of the imaginary (1988b: 177). Imaginary self-constructions objectify and subjugate the self, and others who are to validate this self (Roberts, 2005), as an object of the ego. Specifically, they articulate a self that 
can know itself and know and fulfill its desires. However, such articulations are always bounded by what Lacan called the order of the symbolic (1977b: 206). The symbolic contains all of the linguistic conventions and "sliding signifiers" (Byrne and Healy, 2006: 243) handed down through the generations and therefore is a flawed medium for expressing who we are and what we want. All we ever have at our disposal are the words of others, which we superimpose on what we think we desire, a semblance of what Lacan referred to as objet a (1977b: 239) as that which causes desire, therefore a conscious placeholder for unconscious desire. The symbolic contains an irreducible kernel of lack, a lack of what Lacan called the real (1988b: 219). The real is that which is missing from our articulations, that which we unconsciously desire. Hence the missing real in the symbolic gives rise to desire, which we misconstrue as that which we can articulate, namely the imaginary.

In the imaginary, the lack of the real in the symbolic is glossed over and we avoid the trauma of lack at the center of our being. However, lack continues to make an appearance. Whenever we speak and consciously articulate the imaginary, our speech is filled with disruptions, ambiguities and tensions pointing to the failure of the imaginary to cover over lack (Benvenuto and Kennedy, 1986: 13). Moreover, whenever we obtain what we say we want, we often have the experience that this is not "it" and does not fulfill the desire we have (Lacan, 1977b: 268). We are left instead with the bittersweet pleasure of looking but never finding, something Lacan called jouissance (1988a: 223). Jouissance typically is considered to be phallic (Cederstroem and Spicer, 2014: 192) in that it reaffirms our fantasies that overcoming lack is possible and any disappointment we may experience is not a sign of structural lack but temporary loss that can be recovered. Phallic jouissance in this sense is about the notion of 'alling' (Dickson, 2015: 144) and getting to a place where we have it all without any lack. At times, 
however jouissance can also be feminine (Cederstroem and Spicer, 2014: 192) as the ephemeral perhaps masochistic enjoyment of permanent lack and resting in a stance of 'not-all' (Dickson, 2015: 144). The latter is also an indication that we have traversed the fundamental fantasy. This traversing does not mean that fantasies are abandoned but rather that a different positon or relationship toward fantasy becomes possible (Byrne and Healy, 2006: 246). The traversal of the fantasy opens up existing self-conceptions and a more ethical engagement with desire when the latter is no longer disavowed and externalized as symptom (Healy, 2010: 497) but owned as one's unique and creative struggle with lack (Fink, 2004: 62).

Feminine jouissance in this way may be associated with mourning, or the active working through of loss, as a transformational construction of the self, to whom new opportunities may be available after working through the loss and letting go of the fantasy that lack can be overcome permanently (Oezselcuk, 2006: 230). Phallic jouissance by the same token may be associated with melancholy or the inability to let go of the lost object and the continued chase for it by replacing one object of desire with another and therefore a self-construction foreclosed and tied to its recovery (Oezselcuk, 2006: 230). Melancholy then would also relate to "phantasmic attachment" (Jones and Spicer, 2005: 234) and the clinging to the beatific and horrific sides of fantasies (Glynos, 2008), which maintain the fundamental fantasy that lack can be overcome. While mourning might provide opportunities to unsettle such attachments and thereby traverse the fundamental fantasy so that not only new self-constructions but alternative ideologies and institutional logics (Glynos, 2008) can be articulated.

\section{Data and Interpretation}

The data I wish to examine from this perspective consist of interviews conducted with 61 social entrepreneurs who were selected using purposeful sampling (Glaser, 1978). Specifically, I 
went in search of individuals who described themselves in terms of creating both economic as well as social value irrespective of them working in a for-profit or not-for-profit context. As part of my research is to explore the contestation around the term social entrepreneur, I deliberately kept the selection of interviewees broad and used only an approximation of the term as someone using resources creatively for economic and social benefit. Interviews were conducted in the spring of 2012 and lasted 30 to 60 minutes. 33 of the respondents are female, 28 male. Position titles of interviewees include founder, owner, president and member of the board of directors, president, executive and managing director, chief financial officer, director, partner and manager. Industry sectors include drinking water and food preparation technologies for developing countries, public health services, animal welfare, rural healthcare, childcare, human and social services for the homeless, the poor, and individuals suffering from mental and physical disabilities, financial services for underserved populations, outdoor recreation services for children and the disabled, residential services for adults with developmental disabilities, environmental conservation, youth mentoring, community organizations and a recording studio employing and serving ex-convicts. 46 of the interviewees work for not-for-profit organizations, 14 for for-profits and 1 for an NGO. All identifying information has been removed from the data and interviews are referenced by interview number and line numbers in the transcript.

Following the methodology used in prior research investigating the identity work of entrepreneurs (Gill and Larson, 2014), interviews were open-ended. The purpose was to facilitate "reflection and self-expression" (Gill and Larson, 2014: 528) and to "mobilize 'interpretive repertoires' (Gill and Larson, 2014: 528). Rudimentarily following storytelling methodology (Gabriel, 2000), interviewees were simply invited to tell anything that came to mind and prompted only for reflections in certain areas like what inspires them, what they see as their 
contribution and what challenges they may face. The purpose was to stimulate meaning making (Hendry, 2007: 494) by being a "fellow traveler" (Gabriel, 1995: 481) encouraging any narrative the interviewee wanted to share.

Building on prior research investigating the identities of social entrepreneurs in which it was suggested that narrative analysis is particularly appropriate for studying social entrepreneurship (Jones et al., 2008: 342), the interviews were analyzed following the guidelines of narrative inquiry found suitable especially for identity research (Morison and Macleod, 2013; Ollerenshaw and Creswell, 2002; Polkinghorne, 2007; Sermijn, Devlieger and Loots, 2008; Rogan and De Kock, 2005). Given the Lacanian framework employed here, I fleshed out narrative inquiry with guidelines provided for Lacanian discourse analysis (Parker, 2005; 2010) and loosely followed the steps for interpretation conducive to a psychoanalytic reading of texts (Saville Young, 2014). That is, I sought to analyze the narratives in a concentric reading by working from the content and structural layers through to the interruptions, formulations and reflexivity that open up a more psychoanalytic perspective and more complex understandings of a text including the difficulties of stepping out of it to say something about it while being constituted in and through it (Saville Young, 2014: 283). The aim was to explore not only how discourses were drawn on as resources for identity constructions but importantly how this may be understood in relation to unconscious desire, fantasies and lack. This was a concentric process because the aim was to encircle the texts not by way of closing down readings but to open them up and amplify what might be transformational in my readings inviting experimentation and movement as a "change without guarantees or predetermined ideals" (Oezselcuk, 2006: 231). I therefore followed the progression of steps outlined previously (Saville Young, 2014: 283) and first coded the interviews for content and structure, or what discourses were drawn on 
by the narrators and how these related to one another to enable certain subject positions providing particular resources for imaginary constructions of the self. I then moved to the layer of "interruptions" (Saville Young, 2014: 283) focusing on ambiguities and tensions and the unsettling of the imaginary. Additionally, I examined certain formulations and recurring discursive movements in the narratives and how the imaginary was unsettled but also repaired. Finally, I reflected on such readings of the interviews in light of my own fantasmatic attachments, imaginary constructions and jouissance to which I return in the concluding section.

While the methodology presented here may be congruent with the use of a psychoanalytic approach as grounded theory (Arnaud, 2012: 1125), it is not designed to support theory testing. Moreover, while applying a Lacanian perspective to empirical data, especially interview data, is in itself not unproblematic (Hoedemakers and Keegan, 2010: 1022), I sought to keep with an approach that still renders it valuable for illuminating "micro-moments of organization/self-making" (Harding, 2007: 1764), while remaining aware that a Lacanian perspective cannot offer closure or generalizable findings (Parker, 2005).

\section{Narratives of Social Entrepreneurs}

I begin the analysis of the narratives by exploring their content and structure.

Specifically, I examine discourses the narrators draw on as they reflect on social entrepreneurship and how these function in relation to one another with regard to identity work and the imaginary construction of the self. As we will see, narrators commonly draw on a number of different discourses, such as the moral imperative to help others and making a difference, to not only describe what social entrepreneurship means to them but, importantly, to constitute this as a unique identity with very personal reasons for assuming it, often described as 
a journey whose destination is both hard-won and gratifying. For instance, Mario, the executive director of a not-for-profit organization serving the disabled describes:

Um, so at its core to me being a social entrepreneur is about a double bottom line. It's very much about upholding the mission of your organization as an entity that's out in the world doing whatever that good is that has earned you that nonprofit status. But it's also paying attention to smart business practices and actually trying to generate revenues in support of that larger mission so it's kind of the combining of two different worlds and that most nonprofit entities don't think about generating revenues that for-profit entities do. My whole career has been in nonprofits and I went back to school and got my MBA in 2010 pretty specifically for this reason. In my experience most people that go into the nonprofit sector is because they have a passion for something. Most don't have the business background or the financial background to run a business and even though a nonprofit has this tax status if you don't actually make revenues then you don't actually survive as an organization. So for me it's sort of the perfect world where I can kind bring the business savvy to the nonprofit organization that's doing the good work. Plus, for me personally it's hugely important that my work is more than a paycheck and, as hokey as it sounds, makes the world a better place and so, um, for me my passion is helping people who are more vulnerable and who need some extra help (60/5-31).

Mario first draws on the discourse of social entrepreneurship as characterized by the dual bottom line of creating both social and economic value and sets this in contrast to nonprofits who seem to focus more on social value while, as he says, not thinking about economic value. When he then describes this as his reason for obtaining a business degree and underlines that an organization that does not pay attention to revenue generation does not survive, we can see how this enables a certain subject position. This subject position is one where social entrepreneurship is not only about balancing social and economic concerns but introducing the import of economic or entrepreneurial concerns to organizations that might otherwise focus too much on social value reiterating social entrepreneurship as the ideological call to expand marketization (Dey and Steyaert, 2010; Seanor and Meaton, 2008).

This particular structure then provides discursive resources from which Mario can construct his identity as someone who brings "business savvy" to nonprofits. By describing this 
as his journey and how he has now arrived at this "perfect world" where he can bring his business skills to the table and fulfill his desire to do good work, we can also see how this allows him to construct an imaginary self as someone who knows who he is and fulfill his desires. He uses words like "more than a paycheck" and "passion" to underline this and we can see how he constructs a fantasy that by making the world a better place, he can find the wholeness and unity that cover over any lack he might otherwise experience as a stance of 'all-ing' driven by phallic jouissance. This is also reiterated when he refers to those whom he helps as "more vulnerable", positioning him as someone who is less vulnerable or not vulnerable at all. Moreover, by referring to this in juxtaposition to the "perfect world" he seems to have found, we can see how the lack in the other, or those who are not in a perfect world, facilitate his own covering over of lack. Put differently, by addressing their lack, Mario no longer has lack in himself, which in turn increases his fantasmatic attachment to capitalist ideologies as it is through his business savvy that this lack can be overcome.

This process of drawing on a number of discourses as resources for an identity that turns social entrepreneurship from a more generic category into a uniquely personal journey and self is also illustrated in Sam's narrative. Sam is the CEO of a not-for-profit healthcare foundation:

I think that a social entrepreneur is someone who can take the time to see a social problem and use their skills to perhaps focus on finding a solution or helping to the best of their abilities even if it may not have much, umm, return in profit but at least have a social return...I do feel that to help the local community is morally right because it is the right thing to do and be there to provide guidance and help to others in need (9/22-37).

Like Mario, Sam draws on the discourse of social entrepreneurship in the context of unique skills and abilities. While unlike Mario, Sam does not stress his business savvy, he nonetheless highlights how social entrepreneurship is a field in which individuals have to use their best abilities to find solutions to social problems. Like Mario, Sam underlines social value in relation 
to helping others in need but he connects this to a moral imperative as the morally right thing to do rather than his passion, as Mario did. Importantly, unlike Mario, Sam deemphasizes the focus on economic value by accepting that social value creation may not allow for much "return in profit". Therefore, while their interpretation on what it means to be a social entrepreneur differs, Sam and Mario are similar in how they construct their imaginary selves around this category as a subject position enabled by drawing on various discursive resources defining the self and its desires. Like Mario, Sam is quite confident that he knows who he is and what he wants.

This process is further illustrated by Gary, president of a not-for-profit facility for autistic children:

Being a social entrepreneur means a certain amount of responsibility...It's more a vocation than a lucrative company...I do it to help the development of autistic children so, uh, they can integrate themselves into the community...I do it to help others because it makes me and my wife feel good (8/16-34).

Like Mario and Sam, Gary describes social entrepreneurship as a very malleable identity. While Mario linked it to bringing business savvy to nonprofits, and Sam to unique abilities used to realize a moral imperative to help, Gary links it to the discourse of vocations. That is, he underlines how social entrepreneurship for him is a personal calling of helping others, which makes him feel good. By juxtaposing the discourse of vocation to the terms "lucrative company", Gary, like Sam, downplays the role of profitability. This in turn allows Gary to construct an imaginary self with clearly definable and obtainable desires, such as helping autistic children, and to find enjoyment and satisfaction in seeing them integrate "into the community". Social entrepreneurship therefore furnishes discursive resources to maintain the fantasy that a unified self can be created and lack overcome. 
Importantly, like for Mario and Sam, it furnishes resources to construct the beatific and horrific sides of particular fantasies to maintain the fundamental fantasy by which this is believed to be possible. For Mario the horrific side, or that which is the readily identifiable reason for why his beatific fantasy of overcoming lack by helping others may not be realized, is the lack of business savvy in organizations that create social value, which he can try to address with his skills. For Sam the horrific side is organizations who value economic over social returns and entrepreneurs who do not take the time to see social problems. Finally, for Gary the horrific side is associated with the profit motive and not following one's calling, and the beatific fantasy of one's calling and taking on the "responsibility" of helping those in need.

What is noteworthy about these fantasies is how both the horrific and beatific sides point to struggle. Unlike horrific aspects of fantasies that would be expected to contain struggle and difficulties as that which is the identifiable obstacle to wish fulfillment, beatific fantasies might be more readily associated with having overcome difficulties and visions of rewards or at least of being at ease while fulfilling desire. The beatific side of entrepreneurship fantasies, for example, might be to have a highly profitable business and to finally obtain what being an entrepreneur is all about as the glorified "heffalump" (Jones and Spicer, 2005: 234) of all that an entrepreneur can hope to attain from ultimate confidence to prestige. By contrast, while the beatific side of social entrepreneurship is of course still about the fulfillment of desire, this seems to be a desire for more struggle. As we have seen, the narrators all suggested that their desire if fulfilled is to help those in need, which by definition involves the continued struggle to do so and the everpresent vigilance to notice their need.

Moreover, the beatific side seems to be constructed in opposition to mainstream ideologies of what business is to be about, also pointing to difficulties, and, as the narrators 
underline, involving foregoing some of the rewards the latter has to offer, such as running a lucrative business. The idea of foregoing returns and tacitly accepting lower rewards for social value creation has been noted before as a characteristic of many social entrepreneurs (Dempsey and Sanders, 2010) and it seems to point here to the idea, that unlike for mainstream entrepreneurs, social entrepreneurs seem to have beatific fantasies that share with the horrific ones an ongoing and ever-present struggle. Consequently, while we have seen a great deal of 'all-ing' and phallic jouissance in these narratives, we also see how through the blurring of the beatific and horrific sides of fantasies there is some sliding into feminine jouissance as the disruption of the possibility of covering over all lack and instead amplifying and resting in a 'not-all' stance (Dickson, 2015).

\section{Disruptions}

I explore this further by focusing more intently on disruptions, ambiguities and tensions in the narratives. Specifically, I examine how the journey toward becoming a social entrepreneur is often accompanied by tragic events and involves a working through of loss, that covers over underlying lack but also unsettles the imaginary construction of the self. I begin with an excerpt from an interview with Cameron, owner of a for-profit financial services firm.

As a social entrepreneur, I feel like I need to be aware of the needs of my clientele base, and since I am dealing with people's financial documents. I believe that the price should meet the amount of work that I put in, rather than having people pay for outrageous prices from a common chain store. After 7 years of working for a well-known company, I had enough of charging clients $\$ 300$ for an hour's worth of work. When you are trying your best to help single parents get more back from their refund, why in the world would you turn around and charge them inflated prices for doing their taxes? I try my best to follow the "Golden Rule" with my clients and staff. In this business, I really need to be conscious of people's privacy and financial situations. I feel my morals and the need to do right by other people needs to be at the forefront when I work one-on-one with clients or staff. Being the money-hungry person never enters my business philosophy...As a person with a disability there were really two things that I wanted more than anything, being accepted as an equal in the professional setting, and I really wanted to find a career where people can view me in a professional way and being able to prepare taxes. I finally 
could say 'I am a professional' at something where people can respect me as a professional (58/3-44).

Cameron, like the other narrators, describes social entrepreneurship by drawing on the discourses of helping and the moral imperative to do so. He uses these as resources to construct an imaginary self in opposition to whom he might be if he still worked for a mainstream company and how this would make him overcharge clients to make money. Therefore, as the other narrators, he constructs an identity in opposition to other businesses and as consciously foregoing some profitability. Unlike Mario who stresses the import of economic returns for nonprofits, Cameron downplays the role of such returns even though he runs a for-profit firm. He sees himself as a social entrepreneur precisely because he charges his clients less and is motivated by a moral obligation to help them. This again underlines how malleable a social entrepreneurial identity is and how profitability is an important marker for differentiating identities but not in a simplistic way by which for-profit social entrepreneurs, like Cameron, are necessarily more interested in profitability than nonprofit social entrepreneurs, like Mario.

What also comes into view in Cameron's narrative is how social entrepreneurship offers resources for beatific and horrific fantasies, again with continued struggle as a hallmark of both, and, as we will see, often as an aspect of the journey of becoming a social entrepreneur. Cameron points to this when he describes how he wanted, more than anything, to be accepted as a professional. He describes himself "as a person with a disability" and his desire to be accepted "as an equal" points to struggles he may have had with being discriminated against. In this way, Cameron's imaginary self is not only defined by his morality to help potentially vulnerable clients but his aspirations for a professional identity. The horrific side of the fantasy therefore is 
not only about battling morally questionable business practices but also about the continued struggle to deal with his disability while being a respected professional.

The imaginary self constructed therefore is not only precarious, as all identities are (Alvesson et al., 2008), and readily unsettled by underlying lack but by the struggle with which lack is covered over. Paradoxically therefore the imaginary self is even more important to maintain as a defense against the anxiety produced by lack but at the same time more porous and fragile as, like Cameron, the social entrepreneur may define the self and desire around a continuous struggle with the problems of those they want to help, the difficulties of foregoing economic returns and, potentially, the need to continue to work through personal trauma. From this perspective, Cameron engages in discursive movement by which he may experience both phallic and feminine jouissance as the 'all' he strives for is for him the 'not-all' of the struggles he continues to face.

We see this dynamic especially in the next narratives in which social entrepreneurs describe working through tragic personal circumstances as that which inspires them to be social entrepreneurs. For example, Joanna, the founder of a not-for-profit organization helping individuals with meningioma brain tumors recounts how she came to be a social entrepreneur:

[This organization] was founded nine years ago in response to providing the support that I felt wasn't available when I was diagnosed with a meningioma brain tumor twelve years ago...it's a slow struggle but we're making headway (laughs)...I think our biggest impact is we have given patients a voice because too many times...they're dismissed...that was my story... so what we try to do is just to let people know...they don't have to be afraid to approach their doctor or...feel like they are going crazy (11/9-58).

Again we see social entrepreneurship as a highly malleable identity to which Joanna has come because of her own illness. The imaginary self she constructs fulfills its desires by helping others so that they may not experience the difficulties she has had, and as she points out: "it's a slow 
struggle". So even as she covers over anxiety provoked by underlying lack and the traumatic loss of her health, the fantasy she is attached to involves the continued struggle with the pain and suffering of those she is helping and the medical establishment in which they have little voice.

From this perspective, the imaginary self created here is continuously at risk of being unsettled not only by the impossibility of objects of desire to be more than placeholders for unconscious desire, but by the precariousness of these objects. As for anyone else, Joanna's attempts at covering over fundamental lack by suggesting that she can find wholeness and fulfillment in what she does, is inevitably unsettled by the experience of not finding what she is looking for. But as she is looking for something that is lacking to begin with, namely to help more and more people who need help because they are gravely ill and struggling with the medical system, lacking both health and support, it seems as if continued lack or the amplification of lack is what Joanna is looking for.

Therefore, what she might articulate is a discursive movement in which she experiences both phallic and feminine jouissance. Joanna may be engaged in mourning as a working through of her own tragic loss of health which continuously opens up her identity rather than foreclosing it. She may also have a melancholic yearning for the return of her former, healthier self, but rather actively engages in crafting a self unsettled by the struggles faced by those she helps. This continued opening up and feminine jouissance of lack may surface when she refers to the slow struggle she is engaged in and then says, "but we're making headway (laughs)". Not only the ambiguity of the word "headway" when referring to an organization that helps individuals with brain tumors but also its retroactively playful presentation as she laughs indicate perhaps feminine and ephemeral enjoyment of not only not finding what she is looking for but of amplifying and celebrating its impossibility. Paradoxically, therefore it is her attempt at finding 
the 'all' unsettled by struggles that are about 'not-all', that creates a space for both phallic and feminine jouissance and multiple traversals of the fantasy.

I explore this dynamic further in Sheri's narrative. She is a partner in a not-for-profit organization helping disabled children train for athletic competitions and shares this:

I think it's important to give back to the community...I really do think that it's important that anyone who is fortunate enough to live a happy and healthy life to give to those who are in need...plus I love to do it...it's an awesome cause...I feel like everyone should have a chance... It helped me with dad's death I guess and a way for me to give back to the community...I do see all the kids and how excited they are to see me... [they] look up to me, and love me...telling me I'm the best partner (laughs)...they appreciate everything I do $(25 / 12-63)$.

Sheri, like other narrators, draws on the discourse of a moral imperative to help those in need but here this is also positioned as a way to work through tragic loss. Like Joanna, Sheri has come to be a social entrepreneur as a result of mourning a loss, not her own health as in Joanna's case, but instead her father's death. In reflecting on how this motivated her to help children with disabilities we can see again how the imaginary self she constructs is unsettled. She seems to go back and forth between the idea that she is acting out of a moral imperative to give back as someone "fortunate enough to live a happy and healthy life", a need to work through her father's death, and the appreciation and love she receives from "the kids". Her desire seems continuously displaced between those three and her laughter as she recounts the kids telling her that she is "the best partner" perhaps points to feminine jouissance and a traversal of fantasy. Her laughter constitutes a disruption of what seems to be the beatific side of her fantasy, namely that she not only has found "an awesome cause" to contribute to for which, in return, she is loved, which itself is lacking as a substitute for her father's loss. Sheri, like Joanna, therefore is moving back and forth between melancholy and the phallic 'all' she is looking for and the mourning that 
allows her to work though this as struggles with not having or being 'all' and the feminine jouissance that accompanies this.

A similar movement comes into view in an interview with Sarah, the executive director of a not-for-profit organization serving children with mental disabilities:

When [my daughter] was first born [with autism] I felt like I let her down completely. But I promised that I would do anything to help her, and now that I think about it, that promise is probably the reason, hmmm, why I started all of this...seeing all of my kids grow up and develop brings me great joy and happiness in my life...I feel like helping out someone that is less well-off than you are is very important...I feel like all businesses should do their part (7/40-65).

Like Sheri and Joanna, Sarah links social entrepreneurship with working through tragic circumstances, in this case, of having a child with a mental disability. In her narrative the anxiety produced by lack is palpable as she recounts how she felt as if she let her daughter down because the latter was born with this illness thereby not only taking personal responsibility but also feeling guilty for something that was not her fault as a way to hang on to the fantasy of the 'all'. The phallic jouissance so produced however also slides into feminine jouissance as the social entrepreneurial identity itself becomes an engine for perpetuating rather than foreclosing her own lack. This lack is amplified as a continued struggle with the very condition she feels so guilty for having "given" to her daughter. It is perpetuated by her taking this on not only for other children but in somehow also becoming their mother when she refers to them as "my kids" and the everpresent demand to help all who are less fortunate while calling "all businesses" to a similar moral mandate. In short, Sarah's narrative is marked by discursive movement and a sliding of phallic and feminine jouissance not as a permanent traversal of the fantasy but as multiple traversals because none of them can be sustained for long. Put differently, in an identity built around 'notall', any attachments to an 'all-ing' cannot be maintained. 


\section{Formulations}

I explore this further by examining the formulations or recurring narrative patterns in the interviews that seem to underline social entrepreneurial identity work as an engine for the unsettling of the imaginary and a space in which lack is continuously amplified. For example, Riley, the owner and founder of a for-profit music recording company employing and seeking to rehabilitate ex-convicts says:

Well, to be completely honest, I don't really know that I feel anything in connection with being a social entrepreneur. I don't look at it like that; I'm just trying to help people, and, yeah, maybe make a profit on the side (laughs)...I was raised to be the best person I can be. I am a compassionate person; I look out for my fellow man... I just don't really feel happy when I'm only trying to help myself get by. When I can use what I have to help someone else improve their life, that's when I really feel awesome; that's what gets me fired up...The only person I employ who has not been to jail before is myself... Well, it started a couple of years back when I met my wife... her little brother got into some trouble with the law...he got screwed by the system... when he got released, he was obsessed with music and the kid had talent... We started tossing around the idea of starting up a recording studio... There are hundreds of people trying to make it big, doing everything they can to just put out ONE hit, ONE song they can use to jumpstart a career... No one... knows who they are, but I do. I enjoy helping these artists, which I am extremely proud of. It's a dog-eat-dog world...I help convicts get back on their feet and live honest and stable lives. I help struggling artists to find success...we make mistakes [that] doesn't mean we lose our value as human beings...Most businesses like to exploit people; mine actually strives to help them (21/22-82).

In this narrative several tensions surface, the first one around the term social entrepreneur.

Similar to the other narrators, Riley attempts to define this term in an idiosyncratic fashion, so

much so that he even questions whether the term can fully encompass who he thinks he is. And like the others, one of the markers for this is the profit motive. Riley runs a for-profit business but downplays the profits as being "on the side", after which he laughs. In this disruption of the narrative, we can hear how this unsettles his imaginary self as someone only motivated to help others. Consequently, in Riley's narrative we can observe an overall pattern or discursive movement by which tensions erupt and are then repaired or covered over. In Riley's case, the 
narrative seems to move from the unsettling of the imaginary around the tensions over the import of profits toward repair as he finds fulfilment in helping others. He also justifies his opposition to what he calls "the system" by recounting how his brother-in-law was "screwed" by it. This difficult experience is then recovered from by how he started his recording studio helping former convicts to fulfill their dream of producing a hit song and getting "back on their feet". Having firmly reestablished the beatific side of his fantasy, he ends by reiterating its horrific side, namely having to battle a "system" that does not respect people's value.

Therefore, we might see in Riley's narrative melancholy or a process by which the lost object of desire cannot be let go of because it would threaten the underlying fundamental fantasy that completion and wholeness can be attained. Riley seems sure that he can overcome the lack that he has articulated as "the system" and find happiness in doing so. Yet, even here there are tensions that threaten this melancholic attachment around the import of making a profit. Like the other social entrepreneurs he is in the business of helping those who struggle operating in a system that does not share his values and goals. As a result, as he continues on this journey, it seems inevitable that his imaginary self will continue to be unsettled and that the movement to repair it, as he seems to do in the end, produces feminine jouissance as a momentary traversing of the fantasy. So again, we see not only discursive movement as a sliding between phallic and feminine jouissance but a fragility of attachments to fantasies with blurred beatific and horrific sides and a covering over of lack that invariably amplifies it.

A similar pattern is produced in the next narrative. Michael, the executive director of a not-for-profit organization in India helping remote villages gain access to drinking water says:

As a child I was rather perturbed about injustices...that I felt were being perpetrated on the poor... One day I realized...that maybe my own father himself was an exploiter of his labor so I went to the laborers and said why don't you organize yourself... They said you can become our new union leader... at age $11 \ldots$ and I organized them...And one day we 
raised a red flag of hammer in sickle in front of my father's house and we shouted slogans. He came out, saw what I was doing, didn't say a word... and within two months' time I was sent off to boarding school... That's when I first realized I needed to do something about the inequalities and injustices in today's world...Social entrepreneurs are starting businesses to help people out...I wanted to help...because everyone deserves the same opportunity to succeed...Businesses today are too worried about making profits. They don't care about communities or the environment or really anything besides making money...It is much harder to be a social entrepreneur but the benefits are much better. You will get more happiness helping people out and changing lives than you would making huge profits" (15/26-67).

Like Riley, Michael constructs his identity through his struggles with the capitalist system, which he describes as exploitative, perpetrating injustices and inflicting harm on communities and the environment. As the other narrators, Michael uses the profit motive as a marker for his imaginary self-construction as someone who does not care only about making money and is willing to forego profits to help people. Unlike the other narrators, Michael is more explicit about an alternative to this system by referring to the Soviet flag and couching his critique in Marxist terms. The latter was tellingly done against his father's wishes and we could explore a rich symbolism here around how he is seeking to defy the patriarch. What this underlines importantly is how the term social entrepreneur encompasses a wide array of struggles from personal to political at the interstice of which Michael defines his imaginary self.

This both strengthens and unsettles his imaginary self and we can see again a discursive movement in which lack surfaces and is covered over as Michael is defined by a struggle with his father that he seems unable to work through. All he says is that he realized his father "was an exploiter" and then without any discussion was sent off to boarding school after his rebellious act of flag-raising and union-organizing. As he trades working through his differences with his father for battling the "injustices in today's world", his imaginary self is unsettled. He alludes to this by referring to how hard it is to be a social entrepreneur. Even as Michael insists that one 
attains more happiness by helping people rather than making a huge profit, we can hear a traversal of the fantasy in how Michael moves from the melancholy associated with the unresolved difficulties with his father to a working through as he mourns the loss of the rewards the system might have offered him. This points to both phallic and feminine jouissance at preserving his desire by the sheer enormity of his aspirations to remedy the injustices of the world. And it is this enormity that keeps the narrative in movement, which in turn promises a continuing shifting and sliding between melancholy and mourning.

What comes into view in the narratives is how discursive movement is produced in the constant unsettling of the imaginary by the impossibility of coming close to obtaining even the conscious objects or placeholders of desire, much less to fulfill desire itself, which I examine further in the narrative by Carry, director of volunteer programs at an in-kind donation center:

I'm a retired retail executive from the department store world, and when I look at the [name of the organization withheld], it is a place for me that allows me to use all of my, um, professional skills and allows me to combine that with my personal and spiritual values into making a real difference in the community...It has been everything that I wanted in terms of...combing all of the pieces of my career, but more importantly for me, my role is really about bringing in volunteers, um, who have professional and life experience skills and finding ways to use their skills within our organization... and bringing them into the field of social entrepreneurship and that is what excites me...One of the best examples I have is a retired process manager from [name of the organization withheld] who came to us and wanted to help...He came back with about ten pages of ideas on how to make the food pantry more efficient... and that was two and half years ago. Since that time he has revamped the entire food pantry...He then went on to do the same thing for the receiving dock and most recently he has totally revamped our warehouse... When you start looking at the world through the eyes of social entrepreneurship, you start looking at the community differently. It's a mindset and you start seeing that 'Wow, there's place for everybody to be a part of it!' What I learned here is that there's a terrible message out there that we're enabling people to be lazy and just sit around and wait for government help but it's not true... I work with people every day who come in for food, get back on their feet, come back and volunteer, come back and be donors. It happens all the time...People do not want to become dependent, they want to be proud and rely on themselves. We can stabilize them, and then get them back on their feet, and allow them to go forward... until they are contributing members to the community (46/96-306). 
As in prior narratives, Carry underlines the malleability of a social entrepreneurial identity by emphasizing that it allows her to combine professional skills with her personal and spiritual values. Drawing on the discourse of making a difference and helping others, she constructs an imaginary self that allows her to define who she is and fulfill her desires. Being a social entrepreneur allows her to fit her skill set and values and in return fulfills her as when she says: "It has been everything that I wanted".

Moreover, social entrepreneurship is how she can use her skills to bring others into the field and extend this mindset ever further. This also introduces several tensions into the narrative. The first one is around whether her organization is about enhancing the entrepreneurial skills of those who benefit from its services or whether this only makes them dependent on hand-outs. The second one is around the social entrepreneurial mindset she describes as an all-pervasive demand to spread the message. As she details how much effort she puts into not only using her professional skills to improve the operations of the organization but also to enlist other volunteers and turn around the lives of the food recipients so that they can become more entrepreneurial, we can see again how the tensions disrupt her imaginary self-construction and beatific fantasies. Literally, even in the best of times, Carry's work is never done. If she is too successful in organizing the food pantry then her recipients may be too dependent on this service, so she must always also work toward making them and others more independent and entrepreneurial. Like Michael, the sheer enormity of this object of desire makes it both more attractive and likely to be unsettled.

In some way it encourages a melancholic attachment to the fundamental fantasy that wholeness is possible, while at the same time requiring a continuous working through and mourning for the sacrifices involved in the current struggles inevitably present even in the 
beatific side of this fantasy. Therefore, the narration of a social entrepreneurial identity is an engine for discursive movement in which a sliding of phallic and feminine jouissance as well as traversals of the fantasy are enabled by the sheer inability of maintaining any position or attachment for too long. The 'all' is always already undermined by the 'not-all' this identity is built around.

\section{Discussion}

It is in this sense that social entrepreneurship circles lack differently than other forms of entrepreneurship and offers different resources for identity construction in particular. Any identity is insecure and potentially built, as in the case of entrepreneurship, on impossible objects of desire just by the sheer inability to define exactly what entrepreneurship is (Jones and Spicer, 2005). However, social entrepreneurial identity is built on not only a lack of definition but as a response to an underlying lack whose continued uncovering is at the heart of what it means to be a social entrepreneur. As we have seen it is the continued lack experienced by social entrepreneurs wishing to help and the lack this continues to amplify for themselves whether it is in always having to relive one's own traumatic circumstances, struggling with the lack of economic rewards, working within a system that exploits people, or always being aware of the struggles of those they attempt to help.

From this perspective, lack is amplified in social entrepreneurial identity construction in the very objects of desire and beatific fantasies created. In this amplification also lies its potential to provide feminine jouissance as an experience by which the fundamental fantasy is traversed simply because horrific and beatific sides of fantasies become too blurred to maintain them. As we have seen in the narratives, it is almost as if the narrators seek out lack in their continued pursuit of struggle. This does not mean that the narratives contained a traversal of the fantasy in 
the clinical sense where analysis might end because the person has permanently taken a different subject position toward lack and is now capable of ethical agency. Instead, what may come to light in the narratives examined here is how discursive movement itself can offer multiple temporary traversals of the fantasy by continuously unsettling the imaginary and melancholic attachments to objects of desire, simply because the latter amplify rather than cover over lack.

While all of this could be used to validate the argument that social entrepreneurship merely strengthens an expanding capitalist ideology by which all problems, including those created by marketization itself, should be solved by applying more of the same thinking and therefore only further entraps social entrepreneurs in fantasmatic attachments that gloss over the contradictions in dominant social logics (Glynos, 2008), this is to miss the complexities of social entrepreneurial identity work. As we have seen, as in all identity work, social entrepreneurs do construct an imaginary self and cover over underlying lack in the way they define themselves in closed-off and fixed ways, as, for example, someone who finds answers and fulfillment in what they do, like Mario who brings business savvy to nonprofits and attains a perfect world. Therefore, by supporting phallic jouissance it could be argued that this falls into the category of 'pseudo-activity' (Cremin 2012: 50) in which anything is done to avoid disrupting the underlying forces leaving capitalist ideologies intact. As prior research has shown much of what goes for alternative ethical discourse can often be reduced to resistance at the level of the symptom (Cremin, 2012: 46), a kind of "decaf resistance" (Contu, 2008) that leaves both power structures and fantasmatic attachments to them intact. This claim could be made even when considering that many of the narrators constructed imaginary selves in opposition to mainstream businesses which were variously described as exploitative, money-hungry and ruthlessly driven by profits. 
However, the way the imaginary selves were constructed around the idea of ongoing struggle unsettles the imaginary and weakens fantasmatic attachments to any existing ideologies because the attachments are to fantasies that are regularly traversed by the very nature of how both beatific and horrific sides amplify lack. I am not suggesting here that social entrepreneurs are potentially more emancipated from imaginary and fantasmatic attachments because they are morally superior. Rather what I am suggesting is that the very space created by an identity that straddles so many contradictory objects of desire, not the least of which is to be ever more social and entrepreneurial, facilitates discursive movements that do not sustain continued fantasmatic attachments for very long. Put simply, to have a social entrepreneurial identity with its emphasis on filling it with highly personal characteristics born out of or addressing struggles with lack, by definition creates a space in which identity cannot remain closed off. In every melancholic foreclosure that gets the social entrepreneur to where he/she desires to be is the breaking open of more struggle, loss and mournful working through of not ever-present and sought-after lack.

This in turn not only empowers social entrepreneurs to experience momentary liberation of the imaginary, it also provides the potential for ethical agency as an alternative market enjoyment. Market enjoyment can certainly be understood as symptomatic and phallic as chasing the lost objects that restore pre-symbolic unity (Byrne and Healy, 2006: 243). But here we see a different kind of enjoyment, namely the enjoyment of amplifying the very lack that the market perpetuates. In so doing, social entrepreneurial identity work also opens up the potential for unsettling macro discourses as a form of micro-resistance (Thomas and Davies, 2005: 690). Social entrepreneurship emerges as an "emancipatory space" (De Cock and Boehm, 2007: 831) in which the deficiencies of capitalist ideologies can be articulated and, importantly, critique can be driven by desire itself as an engine to continuously uncover its lack. 
This then turns around the relationship between marketization and desire, where prior research emphasizes how the market is served by desire which sustains its activities in the chase after continuously displaceable objects of desire. Here instead we may see how desire is served by the market by foregoing the chase and instead looking for and amplifying its lack. It is in the latter dynamic that social entrepreneurship may serve as an alternative, not because it can succeed in fixing this lack, but because it succeeds in reiterating and circling it. Social entrepreneurship as a creative struggle with desire and lack provides creative articulations of all that is missing from capitalist ideologies and this, more than its attempts to fill this in, may hold its empowering and transformational potential.

Specifically, it may offer a space in which the notion of decaf resistance can be transformed. Decaf resistance may itself be a product of phallic jouissance as an articulation of the fantasy that there exists a total and radical act that will once and for all change political structures, which in turn makes smaller, local acts seem bland and irrelevant by comparison (Vidaillet and Gamot, 2015: 1008). Yet, as an expression of feminine jouissance decaf resistance can also be undertaken from a stance of 'not-all'. It may not change all but it may change something and in so doing offer a re-politicized space (Vidaillet and Gamot, 2015: 1008). In the case of social entrepreneurial identity narratives, this may be a space that is emancipatory because the exchange of guilt for ethical signifiers (Cremin, 2012: 57) and the economy of enjoyment that ties us to our master (Contu, 2008: 364) are continuously disrupted. This may not point to an ethics of the real as one radical and free act (Contu, 2008: 377) that will once and for all end capitalist ideology but it does point to innumerable discursive movements that erode the economy of desire on which it is built by, for example, blurring its horrific and beatific fantasies and continuously sliding between phallic and feminine jouissance, melancholy and mourning. 


\section{Conclusion}

Before I present what to me seem important (mis)readings (Young, 2014: 289) of the interview texts illustrating important moments of social entrepreneurial identity work, I would like to reflect on how this is itself an imaginary endeavor (Saville Young, 2014: 289). Specifically, I am mindful that it supports the illusion that we can step out of a text and adopt a metalanguage to make sense of what narrators say (Saville Young, 2014: 288) as a stance of 'alling' (Dickson, 2015: 144). I would like to stress that this was not my conscious intent and instead represents the horrific side of a fantasy in which research subjects are laid claim to in the name of scientific inquiry (Tuck and Yang, 2014). But by implication this also means that a beatific fantasy was at play, one by which I can offer an analysis that is informed by how we are situated in and through a text (Saville Young, 2014: 288). Consequently, my attempts at exploring identity work likely reflect both melancholy and phallic jouissance in relation to my desire not to reduce the narrators' subjectivity to objective findings as well as mourning and feminine jouissance in relation to sharing my readings of the narratives simply as a way to amplify lack that is reiterated even if the particular instances I selected missed the lack experienced by the narrators, as a kind of "productive failure: (Hoedemakers, 2007: 13). As such, when I offer concluding thoughts and formulate what the study contributes to our understanding of social entrepreneurial identity work, my hope is to amplify productive failures as discursive movement and an opening up of how we might think about such work.

One of the ways the study opens this up is by expanding a psychoanalytic perspective on social entrepreneurship (Froggett and Chamberlayne, 2004) to encompass a Lacanian framework. Specifically, by extending a project outlined in the study of entrepreneurship (Jones and Spicer, 2005; 2009) and applying it to a closer inspection of the micro narratives of social 
entrepreneurs (Hervieux et al., 2010; Vasi, 2009), a Lacanian framework offers the potential for a more fine-grained, complex and psychosocial (Fotaki et al., 2012: 1113) understanding of social entrepreneurial identity work. This in turn, fills a gap in the literature (Roscoe, 2011: 323) by not only underlining that social entrepreneurial identity work is a crucial dimension of social entrepreneurship (Howorth et al., 2012; Miller et al., 2012; Pache and Chowhury, 2012; Smith and Woodworth, 2012) but also what its function is in the context of the wider discourses that seem to be unsettled as much by social entrepreneurial identity work as the latter unsettles them.

Consequently, the study offers new avenues for exploring social entrepreneurship as an emancipatory space. Specifically, the study provides a novel understanding of how social entrepreneurial identity work blurs horrific and beatific sides of fantasies and thereby enables momentary traversals of the fundamental fantasy that lack can be overcome. In turn, this offers opportunities for feminine jouissance, by which lack is sought out to preserve desire, as an alternative market enjoyment. This not only offers new avenues for differentiating social entrepreneurship from other kinds of entrepreneurship and alternate forms of market enjoyments, but also for potentially transformative (mis)readings of Lacanian ideas.

The study suggests that the concept of traversing the fantasy may be helpful in exploring discursive movement in narratives by suggesting multiple rather than a single permanent traversal of the fantasy that might fit better with clinical psychoanalysis as the potentially permanent subject position enabled at the end of analysis. By playing instead with the idea of multiple 'permanent' traversals, the power of movement in discourse can be explored further outside a clinical setting that relies on the intervention of an analyst. This then also allows for experimentation with the concept of feminine jouissance, again not as a permanent abandonment 
of phallic jouissance, but rather a temporary form of enjoyment made possible by discursive movement and the blurring of horrific and beatific sides of particular fantasies.

This is particularly relevant for an exploration of social entrepreneurial identity work if one wishes to avoid oversimplified and reductionist approaches suggesting that social entrepreneurial identities can be understood as different because they straddle a dual bottom line and are morally superior. As we have seen here social entrepreneurial identity work is rather more complex as each narrator plays with sliding signifiers in unique and creative ways taking different positions toward the label social entrepreneur, the profit motive, moral imperatives and a range of personal issues, traumas and struggles. By exploring all of these in the context of traversals of fantasies and feminine jouissance, social entrepreneurship comes to light not as a fixed and static identity of morally superior heroes who have answers for how to transform today's capitalist system for the betterment of humankind. Rather it emerges as an identity that is not only under construction and precarious but continuously closing and opening around the melancholic attachment to fantasies and the working through and mourning of this attachment transforming identity without predetermined ideals (Oezselcuk, 2006: 231).

This in turn opens up new avenues for exploring social entrepreneurship as a space for ethical agency, again not because the narrators are morally superior, but because they construct identities in a movement that amplifies lack. Future research could explore this further especially in the context of an economy of desire in which new demands are being made on the market system that are desirable because they cannot be met as a unique expression of actors participating in the system to circle lack while repeatedly traversing the fantasy. A more provocative idea that flows from this may be to explore how capitalist ideology can be experienced as a quasi-analytical setting in which the whole point is to amplify lack and move 
toward different positions in relation to it by the sheer quantity of moments of lack that can be experienced. This perspective may offer new avenues for exploring resistance by moving us beyond phallic and 'all-ing' demands that pit decaffeinated against caffeinated resistance driven by fantasies of all-encompassing real acts of resistance (Contu, 2008). A perspective infused by feminine jouissance helps us mourn such fantasies and re-politicize a space in which to appreciate smaller effects of lack arising when fantastic attachments cannot be maintained.

With regard to such future research, the study also provides a methodological contribution in highlighting how a Lacanian approach can be used to not only study micronarratives but also how this may be done in a concentric and iterative process that plays with texts rather than reducing them to closed-off readings. This offers the opportunity to share transformative moments in research not as a way to make sense of what respondents say but simply to resonate with and potentially amplify various discursive movements. Doing so may be relevant for exploring identity narratives, beyond social entrepreneurship, creating a space in which the precariousness and malleability of such narratives can be examined as one modality of conducting post-fantasmatic research (Byrne and Healy, 2006).

In short, a number of avenues for future research open up when examining social entrepreneurial identity from a psychosocial perspective (Fotaki et al., 2012). In particular, it offers new ways for exploring a stance of 'not-alling' (Dickson, 2015) whereby more attention can be paid to discursive movement that unsettles either/or thinking allowing for both/and. In turn, this opens up a space to investigate alternative (market) enjoyments and resistance driven by amplification of the sheer inability to maintain fantasmatic attachments (Glynos, 2008). This is a space in which to place demands on capitalism whose purpose it is to energize discursive 
movements that change our economy of enjoyment not as an all-encompassing act (Vidaillet and

Gamot, 2015: 1008) but a steady erosion of its fantasmatic attachments.

\section{References}

Alter, K. 2004. Social enterprise typology. Washington, DC: Virtue Ventures LLC.

Alvesson, M., Ashcraft, K.L. and Thomas, R. 2008. Identity matters: Reflections on the construction of identity scholarship in organization studies. Organization, 15(1): 5-28.

Arnaud, G. 2002. The organization and the symbolic: Organizational dynamics viewed from a Lacanian perspective. Human Relations, 55(6), 691-716.

Arnaud, G. 2012. The contribution of psychoanalysis to organization studies and management: An overview. Organization Studies, 33(9): 1121-1135.

Arnaud, G. and Vanheule, S. 2007. The division of the subject and the organization: A Lacanian approach to subjectivity at work. Journal of Organizational Change Management, 20(3): 359369.

Bacq, S. and Janssen, F. 2011. The multiple faces of social entrepreneurship: A review of definitional issues based on geographical and thematic criteria. Entrepreneurship \& Regional Development: An International Journal, 23:5-6, 373-403

Benvenuto, B. and Kennedy, R. 1986. The works of Jacques Lacan. New York: St. Martin's Press.

Bornstein, 1998. Changing the world on a shoestring. Atlantic Monthly, 281(1): 34-39.

Boschee, J. and McClurg, J. 2003. Towards a better understanding of social entrepreneurship: Some important distinctions. Retrieved at http://www.caledonia.org.uk/papers, accessed May 31, 2010.

Brown, A.D. and Lewis, M.A. 2011. Identities, discipline and routines. Organization Studies, 32(7): 871-895.

Byrne, K. and Healy, S. 2006. Cooperative subjects: Toward a post-fanasmatic enjoyment of the economy. Rethinking Marxism, 18(2): 241-258.

Cederstroem, C. and Spicer, A. 2014. Discourse of the real kind: A post-foundational approach to organizational discourse analysis. Organization, 21(2): 178-205.

Contu, A. 2008. Decaf resistance: On misbehavior, cynicism, and desire in liberal workplaces. Management Communication Quarterly, 21(3): 364-379. 
Contu, A., Driver, M. and Jones, C. 2010. Jacques Lacan with organization studies. Organization, 17(3): 307-315.

Costas, J. and Fleming, P. 2009. Beyond dis-identification: A discursive approach to selfalienation in contemporary organizations. Human Relations, 62(3): 353-378.

Cremin, C. 2009. Never employable enough: The (im)possibility of satisfying the boss's desire. Organization, 17(2): 131-149.

Cremin, C. 2012. The social logic of late capitalism: Guilt fetishism and the culture of crisis industry. Cultural Sociology, 6(1): 45-60.

Dacin, M.T., Dacin, P.A., and Tracey, P. 2011. Social entrepreneurship: A critique and future directions. Organization Science, forthcoming.

DeCock, C. and Boehm, S. 2007. Liberalist fantasies: Zizek and the impossibility of the open society. Organization, 14(6): 815-836.

Dees, G.J. and Economy, P. 2001. Social entrepreneurship. In G.J. Dees, J. Emerson and P. Economy (eds.), Enterprising nonprofits: A toolkit for social entrepreneurs. New York: John Wiley and Sons, Inc.

Dempsey, S.E. and Sanders, M.L. 2010. Meaningful work? Nonprofit marketisation and work/life balance in popular autobiographies of social entrepreneurship. Organization, 17(4): 437-459.

Dey, P. 2006. The rhetoric of social entrepreneurship: Paralogy and new language in academic discourse. The Third Movements of Entrepreneurship. Cheltenham, UK: Edward Elgar Publishing: 121-142.

Dey, P., and Steyaert, C. 2010. The politics of narrating social entrepreneurship. Journal of Enterprising Communities, 4(1): 85-108.

Dickson, A. 2015. Hysterical blokes and the Other's jouissance. Gender, Work and Organization, 22(2): 139-147.

Driver, M. 2009a. "Struggling with Lack: A Lacanian Perspective on Organizational Identity", Organization Studies 30(1): 55-72.

Driver, M. 2009b. Encountering the Arugula Leaf: The Failure of the Imaginary and Its Implications for Research on Identity in Organizations. Organization, 16(4): 487-504.

Eikenberry, A.M. 2009. Refusing the market: A democratic discourse for voluntary and nonprofit organizations. Nonprofit and Voluntary Sector Quarterly, 38(4): 582-596.

Fink, B. 2004. Lacan to the letter. Minneapolis, MN: University of Minnesota Press. 
Fotaki, M., Long, S. and Schwartz, H. 2012. What can psychoanalysis offer organization studies today? Taking stock of current developments and thinking about future directions. Organization Studies, 33(9): 1105-1120.

Froggett, L. and Chamberlayne, P. 2004. Narratives of social entreprise. Qualitative Social Work, 3(1): 61-77.

Gabriel, Y. 1995. The unmanaged organization: stories, fantasies and subjectivity. Organization Studies, (16): 477-502.

Gabriel, Y. 2000 Storytelling in organizations. New York: Oxford University Press.

Gill, R. and Larson, G.S. 2014. Making the ideal (local) entrepreneur: Place and the regional development of high-tech entrepreneurial identity. Human Relations, 67(5): 519-542.

Glaser, B.G. 1978. Theoretical sensitivity. Advances in the methodology of grounded theory. Mill Valley, California: Sociology Press.

Glynos, J. 2008. Ideological fantasy at work. Journal of Political Ideologies, 13(3): 275-296.

Harding, N. 2007. On Lacan and the becoming-ness of organizations/selves. Organization Studies, 28(11): 1761-1773.

Healy, S. 2010. Traversing the fantasies, activating desires: Economic geography, activist research, and psychoanalytic methodology. The Professional Geographer, 62(4): 496-506.

Hendry, P.M. 2007. The future of narrative. Qualitative Inquiry, 13(4): 487-498.

Hervieux, C., Gedajlovic, E. and Turcotte, M.F.B. 2010. The legitimization of social entrepreneurship. Journal of Enterprising Communities, 4(1): 37-67.

Hoedemakers, C. 2007. Performance pinned down: A Lacanian analysis of subjectivity at work: ERIM, 2008.

Hoedemakers, C. and Keegan, A. 2010. Performance pinned down: Studying subjectivity and the language of performance. Organization Studies, 31(8): 1021-1044.

Howorth, C., Parkinson, C. and MacDonald, M. 2011. Discursive chasms: An examination of the language and promotion of social enterprise. In A. Southern (ed.) Enterprise, deprivation and social exclusion: The role of small business in addressing social and economic inequalities. London: Sage, 249-260.

Howorth, C., Smith, S.M. and Parkinson, C. 2012: Social learning and social entrepreneurship education. Academy of Management Learning \& Education, 11(3): 371-389.

Jokinen, E. 2004. The makings of mother in diary narratives. Qualitative Inquiry, 10(3): 339359. 
Jones, C., and Spicer, A. 2005. The sublime object of entrepreneurship. Organization, 12: 223246.

Jones, C. and Spicer, A. 2009. Unmasking the entrepreneur. Cheltenham, UK: Edward Elgar. Jones, C., and Murtola, A. 2012. Entrepreneurship and expropriation. Organization, 19(5): 635655.

Jones, R., Latham, J. and Betta, M. 2008. Narrative construction of the social entrepreneurial identity. International Journal of Entrepreneurial Behavior \& Research, 14(5): 330-345. Lacan, J. 1977a. Ecrits. New York: Norton.

Lacan, J. 1977b. The four fundamental concepts of psychoanalysis. London: Hoghart Press.

Lacan, J. 1988a. The seminar of Jacques Lacan, Book I: Freud's papers on technique 1953-1954. New York: Norton.

Lacan, J. 1988b. The seminar of Jacques Lacan, Book II: The ego in Freud's theory and in the technique of psychoanalysis 1954-1955. New York: Norton.

Martin, M. 2004. Surveying social entrepreneurship: toward an empirical analysis of the performance revolution in the social sector. Center for Public Leadership, St. Gallen, Switzerland.

Martin, R.J. and Osberg, S. 2007. Social entrepreneurship: The case for definition. Stanford Social Innovation Review, Spring: 29-39.

Miller, T.L., Grimes, M.G., McMullen, J.S. and Vogus, T.J. 2012. Venturing for others with heart and head: How compassion encourages social entrepreneurship. Academy of Management Review, 37(4): 616-640.

Miller, T.L., Wesley, C.L. and Williams, D.E. 2012. Educating the minds and caring hearts: Comparing the views of practitioners and educators on the importance of social entrepreneurship competencies. Academy of Management Learning \& Education, 11(3): 349-370.

Morison, T. and Macleod, C. 2013. A performative-performance analytical approach: Infusing Butlerian theory into the narrative-discursive method. Qualitative Inquiry, 19(8): 566-577.

O’Connor, E.S. 2006. Location and relocation, visions and revisions: opportunities for social entrepreneurship. In Steyaert, J, and Hjorth, D. (Eds.) Entrepreneurship as social change: a third movements in entrepreneurship book. Cheltenham, UK: Edward Elgar: 79-96.

Oezselcuk, C. 2006. Mourning, melancholy, and the politics of class transformation. Rethinking Marxism, 18(2): 225-240.

Ollerenshaw, J. and Creswell, J.W. 2002. Narrative research: A comparison of two restorying data analysis approaches. Qualitative Inquiry, 8(3): 329-347. 
Pache, A.C. and Chowdhury, I. 2012. Social entrepreneurs as institutionally embedded entrepreneurs: Toward a new model of social entrepreneurship education. Academy of Management Learning \& Education, 11(3): 494-510.

Parker, I. 2005. Lacanian discourse analysis in psychology. Theory \& Psychology, 15(2): 163182.

Parker, I. 2010. Psychosocial studies: Lacanian discourse analysis negotiating interview text. Psychoanalysis, Culture \& Society, 15(2): 156-172.

Parkinson, C. and Howorth, C. 2008. The language of social entrepreneurs. Entrepreneurship and Regional Development, 20: 285-309.

Paulsen, N. and McDonald, A. 2010. Doing social enterprise: a reflection and view from the field. Third Sector Review, 16(2): 109-126.

Peredo, A.M. and McLean, M. 2006. Social entrepreneurship: A critical review of the concept. Journal of World Business, 41: 56-65.

Polikinghorne, D.E. 2007. Validity issues in narrative research. Qualitative Inquiry, 13(4): 471486.

Roberts, J. 2005. The power of the 'imaginary' in disciplinary processes. Organization, 12(5): 621-645.

Roberts, D. And Woods, C. 2005. Changing the world on a shoestring: The concept of social entrepreneurship. Business Review, autumn, 45-51.

Rogan, A.I. and De Kock, D. M. 2005. Chronicles from the classroom: Making sense of the methodology and methods of narrative analysis. Qualitative Inquiry, 11(4): 628-649.

Roscoe, P. 2011. The unbearable emptiness of entrepreneurship. Ephemera, 11(3): 319-324.

Saville Young, L. 2014. Becoming other to oneself: Misreading the researcher through Lacanian discourse analysis. In I. Parker and D. Pavon-Cuellar (eds.) Lacan, discourse, event: New psychoanalytic approaches to textual indeterminacy. London: Routledge, 279-290.

Seanor, P. and Meaton, J. 2008. Learning from failure, ambiguity and trust in social enterprise, Social Enterprise Journal, 4(1): 24-40.

Sermijn, J., Devlieger, P. and Loots, G. 2008. The narrative construction of the self: Selfhood as a rhizomatic story. Qualitative Inquiry, 14(4): 632-650.

Smith, W.K., Besharov, M.L., Wessels, A.K. and Chertok, M. 2012. A paradoxical leadership model for social entrepreneurs: Challenges, leadership skills, and pedagogical tools for managing social and commercial demands. Academy of Management Learning \& Education, 11(3): 463478. 
Smith, I.H. and Woodworth, W.P. 2012. Developing social entrepreneurs and social innovators: A social identity and self-efficacy approach. Academy of Management Learning \& Education, 11(3): 390-407.

Stavrakakis, Y. 2008. Subjectivity and organized other: Between symbolic authority and fantasmatic enjoyment. Organization Studies, 29(7): 1037-1059.

Tan. W., Williams, J. and Tan, T. 2005. Defining the 'social' in 'social entrepreneurship': Altruism and entrepreneurship. International Entrepreneurship and Management Journal, 1: 353365 .

Teasdale, S. 2011. What's in a name? Making sense of social enterprise discourses. Public Policy and Administration, 25, doi: 10.1177/0952076711401466.

Thomas, R. and Davies, A. 2005. Theorizing the micro-politics of resistance: New public management and managerial identities in the UK public services. Organization Studies, 26(5): 683-706.

Thompson, J., Alvy, G. and Lees, A. 2000. Social entrepreneurship: A new look at the people and the potential. 38(5): 328-338.

Tuck, E. and Yang, K.W. 2014. Unbecoming claims: Pedagogies of refusal in qualitative research. Qualitative Inquiry, 20(6): 811-818.

Vasi, I.B. 2009. New heroes, old theories? Toward a sociological perspective on social entrepreneurship. In R. Ziegler (ed.), An introduction to social entrepreneurship: Voices, preconditions, contexts. Cheltenham, UK: Edward Elgar.

Vidaillet, B. and Gamot, G. 2015. Working and resisting when one's workplace is under threat of being shut down: A Lacanian perspective. Organization Studies, 36(8): 987-1011.

Wolgemuth, J.R. and Donohue, R. 2006. Toward an inquiry of discomfort: Guiding transformation in 'emancipatory' narrative research. Qualitative Inquiry, 12(5): 1022-1039.

Ybema, S., Keenoy, T., Oswick, C., Beverungen, A., Ellis, N. and Sabelis, I. 2009. Articulating identities. Human Relations, 62(3): 299-322.

Zahra, S.A., Gedajlovic, E., Neubaum, D.O. and Shulman, J.M. 2009. A typology of social entrepreneurs. Journal of Business Venturing, 24(5): 519-32.

Zietlow, J.T. 2001. Social entrepreneurship: Managerial, finance and marketing aspects. Journal of Nonprofit and Public Sector Marketing, 9(1-2): 19-43. 